Journal of Engineering Sciences, Assiut University, Vol. 37, No. 2, pp. 319-330, March 2009.

\title{
STRUCTURAL SEMI-LIGHTWEIGHT CONCRETE USING CRUSHED HOLLOW BLOCK (CHB) AS LIGHTWEIGHT AGGREGATE
}

\author{
Faiz A. M. Mirza \\ Civil Engineering Department, Umm Al-Qura University, Makkah, Saudi \\ Arabia.P.O.Box: 6298, E-mail: faizmirza@hotmail.com
}

(Received February 20, 2009 Accepted March 5, 2009)

\begin{abstract}
The properties of structural lightweight concrete produced using crushed hollow block as semi-lightweight coarse aggregate were investigated. The crushed hollow block (CHB) was treated by solution of silica fume and calcium hydroxide of different concentrations (10 and 20\%) by weight of mixing water. The performance of semi-lightweight concrete made with treated $\mathrm{CHB}$ and containing silica fume as an additional cementitious material at different percents $(0,5,10,15 \%$ by weight of cement) was investigated on terms of physical properties. Test results proved that, using treated artificial semi-lightweight aggregate increase the compressive and flexural strengths of concrete, the idea of using cured aggregate by pozzolanic material solution must be taken into consideration. The need of using supplementary cementitious materials such as silica fume must be detected to enhance the performance of semilightweight concrete
\end{abstract}

\section{INTRODUCTION}

One way of reducing the mass or dead load of structures is using lightweight concrete in the construction. Lightweight concrete can easily produced by using light weight aggregates.

Lightweight aggregates are broadly classified in to two types: Natural (Pumice, Diatomite, Volcanic Cinders, etc.) and Artificial (Perlite, Expanded Shale, Clay, Slate, Sintered PFA, etc.). Lightweight aggregates can be used to produce low density concretes required for building applications like cladding panels, curtain walls, composite flooring systems, and load-bearing concrete blocks, [1,2].

Structural lightweight concrete has its obvious advantages of higher strength to weight ratio, better tensile strain capacity, lower coefficient of thermal expansion, and superior heat and sound insulation characteristics due to air voids in the lightweight aggregate. Also the reduction in the dead weight of the construction materials, by the use of lightweight aggregate in concrete, could result in a decrease in cross section of Concrete structural elements (columns, beams, plates, foundation). It is also possible to reduce steel reinforcement $[3,4]$.

Many laboratory studies, evaluate the effect of using different units weight aggregate including lightweight bricks, lightweight expanded clay and normal weight gravel without the use of natural fine aggregate on the physical and mechanical properties of lightweight of concrete. It was reported that a lightweight concrete with $50 \mathrm{MPa}$ cube compressive strength and $1800 \mathrm{Kg} / \mathrm{m} 3$ fresh density can be produced. 
Also it was reported that the addition of mineral admixtures increased the compressive strength of concrete produced with lightweight expanded perlite aggregate $[5,6,7]$.

For the production of such high quality concretes there is a need for a better understanding of the mechanisms by which strength is generated in such systems. This is necessary for making the correct choice of aggregates and for developing guidelines for controlled production of lightweight aggregates for this purpose. In systems of this kind, the aggregate is weaker than matrix, and therefore considered to be the weak constituent $[8,9,10]$.

In this research a new technology was developed to enhance the quality of an artificial lightweight aggregate (crushed hollow block) by immersing it in solution of silica fume in order to let the silica fume particles get through the aggregates and try to packed some of the voids and consequently obtain aggregates different in their strength, absorption and pozzolanic activity.

\section{EXPERIMENTAL WORK}

The present study covers the use of crushed hollow block as lightweight coarse aggregate in concrete containing silica fume as supplementary cementitious materials at different levels namely: $0,5,10$, and $15 \%$ as an addition to cement. The crushed hollow block aggregate was treated by solutions of silica fume and calcium hydroxide (10 and 20\% concentration solution). The performance of lightweight concrete made with crushed hollow block as coarse aggregate was studied in terms of compressive and flexural strengths up to 28 days. The main variables, experimental program, are described and reported in Table 1. Material properties, experiments procedures, mix design, casting and tested models are also reported in the following sections.

Table 1:Experimental program.

\begin{tabular}{|c|c|c|c|c|c|}
\hline \multirow{2}{*}{$\begin{array}{c}\text { Solution } \\
\text { Concentration } \\
(\%)\end{array}$} & \multirow{2}{*}{$\begin{array}{c}\text { Test Age } \\
\text { (days) }\end{array}$} & \multicolumn{4}{|c|}{$\begin{array}{l}\text { Silica Fume } \\
\text { Content }(\%)\end{array}$} \\
\hline & & 0 & 5 & 10 & 15 \\
\hline \multirow{4}{*}{0} & 3 & ** & * & "** & "* \\
\hline & 7 & $*$ & $*$ & $*$ & $*$ \\
\hline & 28 & $*$ & $*$ & $*$ & $*$ \\
\hline & 90 & $*$ & $*$ & $*$ & $*$ \\
\hline \multirow{4}{*}{10} & 3 & "* & (* & "** & * \\
\hline & 7 & $*$ & $*$ & $*$ & $*$ \\
\hline & 28 & $*$ & $*$ & $*$ & $*$ \\
\hline & 90 & $*$ & $*$ & $*$ & $*$ \\
\hline \multirow{4}{*}{20} & 3 & $*$ & * & "** & (* \\
\hline & 7 & $*$ & $*$ & $*$ & $*$ \\
\hline & 28 & $*$ & $*$ & $*$ & $*$ \\
\hline & 90 & $*$ & $*$ & $*$ & $*$ \\
\hline
\end{tabular}

* Three samples were conducted for flexure and two for compression test. 


\section{MATERIAL PROPERTIES}

Crushed hollow block (CHB) was used as lightweight aggregate. In this investigation, blocks were broken manually. ASTM D-75 and ASTM C-136 and C-29 were used for sampling, grading, unit weight and fineness modulus of aggregate. Maximum aggregate size was $10 \mathrm{~mm}$. Natural normal weight fine clean sand free from any impurities such that silt, learn, clay and organic compound aggregate was used. The fine aggregate was confirmed the ASTM C-33 requirements.

A locally produced ordinary portland cement (Type I, Arabian cement company Ltd. Rabigh Cement Plant) was used in this investigation. The cement content was $400 \mathrm{~kg} / \mathrm{m}^{3}$. The water has been used for mixing and curing of all concrete mixes and specimen's was clean fresh water free from any impurities.

Silica fume is a fine powder which acts as a microscopic concrete pore filler. It is based on a chloride free pozzolanic material consisting of over $90 \%$ silicon dioxide. Its addition to the cement mix will yield a concrete especially able to cope with the Middle Eastern environment. The physical and chemical properties of the silica fume used in this vestigation are reported in Tables 2 and 3, respectively.

Table-2: Physical properties of the silica fume.

\begin{tabular}{||c|c||}
\hline Appearance & Fine powder \\
\hline Bulk Density $\left(\mathrm{kg} / \mathrm{m}^{3}\right)$ & $300-600$ \\
\hline Surface Area $\left(\mathrm{m}^{2} / \mathrm{kg}\right)$ & $18,000-22,000$ \\
\hline Chloride Content & Nill to BS 5075 \\
\hline Ignition Loss $(\%)$ & $<3 \%$ \\
\hline Flammability & Non-flammable \\
\hline
\end{tabular}

Table -3: Chemical compositions of the silica fume.

\begin{tabular}{||c|c|c|c|c|c|c|c||}
\hline \hline OXIDES & $\mathrm{SIO}_{2}$ & $\mathrm{FE}_{2} \mathrm{O}_{3}$ & $\mathrm{AL}_{2} \mathrm{O}_{3}$ & $\mathrm{MGO}$ & $\mathrm{CAO}$ & $\mathrm{NA}_{2} \mathrm{O}$ & $\mathrm{K}_{2} \mathrm{O}$ \\
\hline$(\%)$ & $>90$ & $<1.5$ & $<1.0$ & $<1.0$ & $<1.0$ & $<0.5$ & $<0.5$ \\
\hline \hline
\end{tabular}

Superplasticizer is a chloride free, superplasticing admixture based on selected sulphonated naphthalene polymers. It is supplied as a brown solution which instantly disperses in water. Superplasticizer disperses the fine particles in the concrete mix, enabling the water content of the concrete to perform more effectively. The very high levels of water reduction possible allow major increases in strength to be obtained.

All specimens were immersed in water tank 24 hours after casting (after finishing initial setting time) to complete hydration reaction through curing period of 3 days. At the end of curing period, the specimens were removed from water tank and placed at room temperature until test age.

Compressive strength and flexural strength tests were performed by universal testing machine, equipment that measures the compressive and splitting bending strengths directly according to the ASTM specifications ASTM C-39 and ASTM C-78, respectively. The concrete specimens were $150 * 150 * 150 \mathrm{~mm}(6 * 6 * 6$ in) cubes and $350 * 100 * 100 \mathrm{~mm}(14 * 4 * 4$ in) beams to determine the compressive and bending strength, respectively. 


\section{RESULTS AND DISCUSSIONS}

The test results of artificial lightweight aggregate (CHBA) concrete for compressive strength and flexural strength are presented in Table 4.

Table 4: Crushed hollow block aggregate (CHBA) concrete tests results.

(a) Compressive strength test.(MPa)

\begin{tabular}{|c|c|c|c|c|c|}
\hline \multirow{2}{*}{$\begin{array}{c}\text { Solution } \\
\text { Concentration } \\
(\%) \\
\end{array}$} & \multirow{2}{*}{$\begin{array}{c}\text { Test Age } \\
\text { (days) }\end{array}$} & \multicolumn{4}{|c|}{ Silica Fume Content (\%) } \\
\hline & & 0 & 5 & 10 & 15 \\
\hline \multirow{3}{*}{0} & 3 & 22.56 & 27.73 & 21.68 & 20.58 \\
\hline & 7 & 24.42 & 31.81 & 30.67 & 33.53 \\
\hline & 28 & 29.78 & 36.61 & 34.25 & 36.18 \\
\hline \multirow{3}{*}{10} & 3 & 25.78 & 26.7 & 21.34 & 21.55 \\
\hline & 7 & 30.63 & 33.9 & 30.855 & 31.68 \\
\hline & 28 & 32.12 & 37.77 & 35.44 & 36.36 \\
\hline \multirow{3}{*}{20} & 3 & 19.44 & 21.28 & 21.25 & 21.61 \\
\hline & 7 & 26.17 & 30.95 & 30.74 & 31.37 \\
\hline & 28 & 30.10 & 34.28 & 34.34 & 34.06 \\
\hline
\end{tabular}

(b) Flexural strength test.(MPa).

\begin{tabular}{||c||c|c|c|c|c||}
\hline \multirow{2}{*}{$\begin{array}{c}\text { Solution } \\
\text { Concentration } \\
(\%)\end{array}$} & \multirow{2}{*}{$\begin{array}{c}\text { Test Age } \\
(\text { day })\end{array}$} & \multicolumn{4}{|c|}{ Silica Fume Content (\%) } \\
\cline { 3 - 6 } & 3 & 2.57 & 3.15 & 3.11 & 2.97 \\
\hline \hline \multirow{3}{*}{0} & 7 & 3.05 & 3.59 & 3.59 & 4.06 \\
\cline { 2 - 6 } & 28 & 3.24 & 4.47 & 4.89 & 5.01 \\
\cline { 2 - 6 } & 3 & 2.68 & 3.38 & 3.47 & 3.80 \\
\hline \hline \multirow{3}{*}{10} & 7 & 3.43 & 4.00 & 3.93 & 4.21 \\
\cline { 2 - 6 } & 28 & 3.60 & 5.03 & 4.93 & 4.98 \\
\cline { 2 - 6 } & 3 & 2.36 & 3.28 & 3.50 & 3.79 \\
\hline \hline \multirow{2}{*}{20} & 7 & 2.98 & 4.03 & 4.07 & 3.96 \\
\cline { 2 - 6 } & 28 & 4.07 & 5.03 & 5.03 & 5.01 \\
\hline
\end{tabular}

\section{Compressive Strength:}

The effect of using cured aggregate by silica fume solution at different concentration on compressive strength of concrete made with CHBA (crushed hollow block aggregate) are illustrated in Figures 1 (a), (b)\& (c). From these figures it was observed for all silica fume content the compressive strength was increased by nearly the same rate up to 28 days for all silica fume content and for all cured aggregate. 
The effect of silica fume addition on compressive strength of concrete made from CHBA without curing can be negligible, as shown in Figure 1 (a), While it can be observed that, the effect of silica fume addition on compressive strength of concrete made from cured aggregate (10, $20 \%$ solution concentration) can be measured.

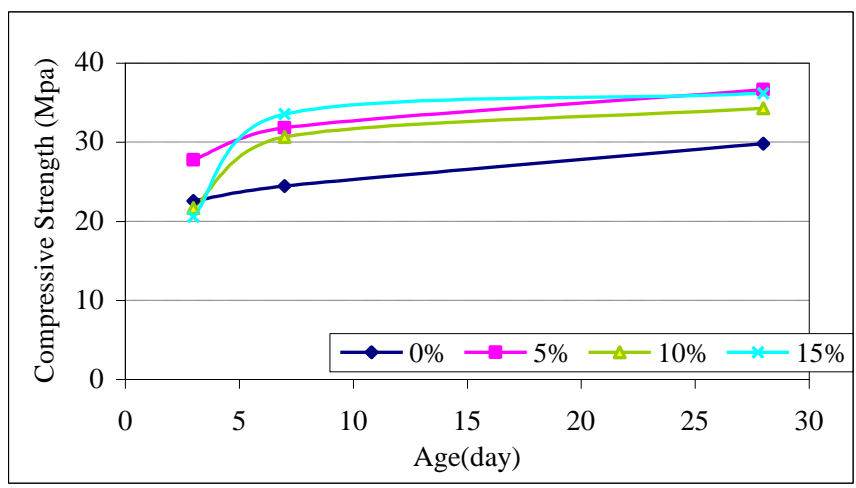

a) Cured Agg. with 0\% Silica fume solution.

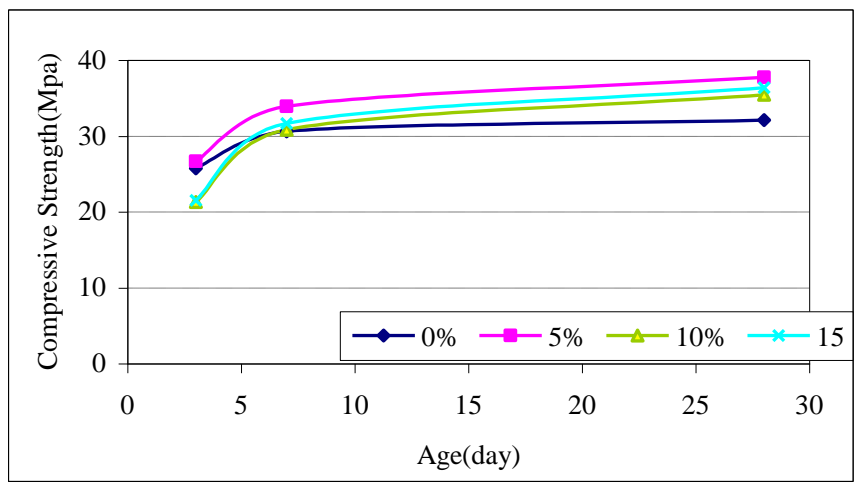

b) Cured Agg. with 10\% Silica fume solution .

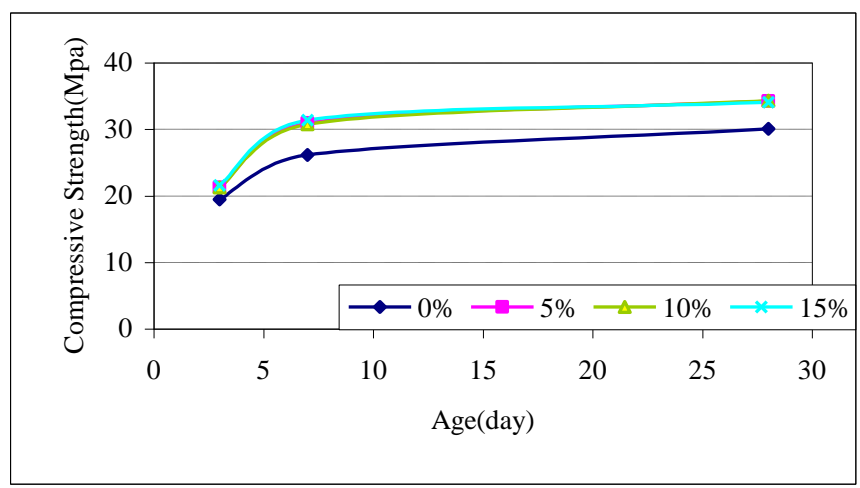

c) Cured Agg. with 20\% Silica fume solution.

Figure 1: Effect of curing aggregate with silica fume on compressive strength for CHBA concrete at different percent of silica fume addition.

The compressive strength of CHBA concrete at 28 days was selected to study the effect of cured aggregate and silica fume addition shown in Figures $2 \& 3$ 
respectively. From figures 4-11, 4-12 it was found that the compressive strength of cured aggregate concrete increased by about $99.5 \%$ comparing by that occurred when used non cured aggregate. Also the compressive strength of cured specimens increased by about $96.92 \%$ by increasing silica fume content as addition from 5 up to $10 \%$.

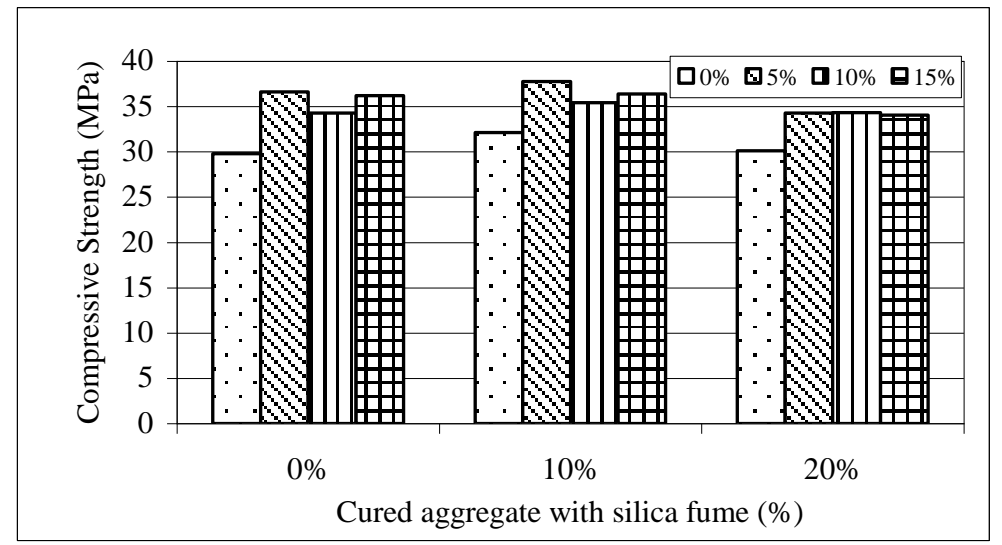

Figure 2: Effect of curing aggregate with silica fume on compressive strength for $\mathrm{CBH}$ concrete at different silica fume addition.

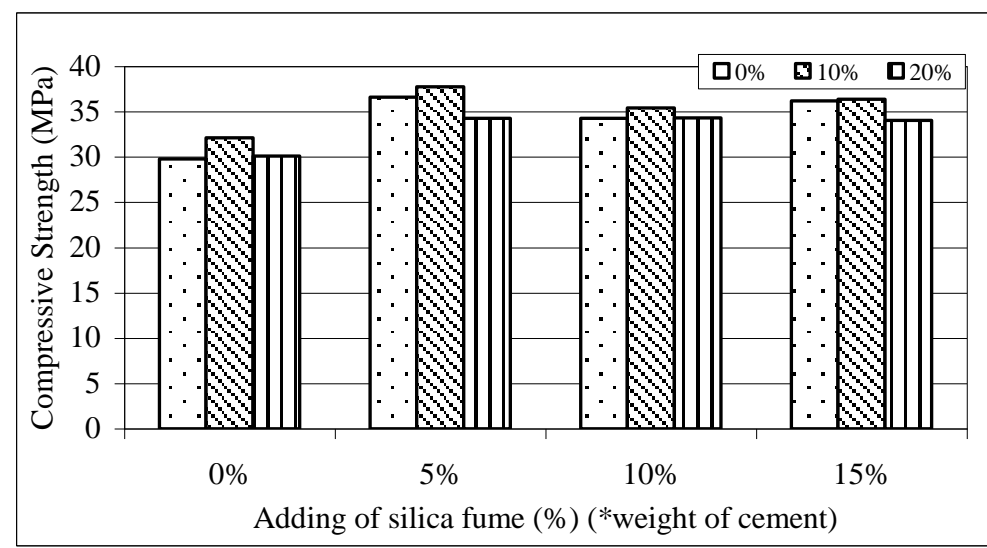

Figure 3: Effect of adding silica fume on compressive strength for CHBA concrete for different cured aggregate solution concentration.

The effect of type of aggregate (cured \& uncured) on compressive strength of CHBA concrete are illustrated in Figure 4 (a), (b), (c) \& (d). Figure 4 (a), (b) explain the effect of silica fume content $(0,5 \%)$ as addition on the concrete compressive strength of concrete containing cured aggregate $(0,10,20 \%$ silica fume solution concentration). From these figure it can be observed that the effect of using cured aggregate can be negligible up to 7 days, while the effect of using cured aggregate appeared clearly at 28 days compressive strength.

By increase the silica fume content up to $15 \%$ the effect of using cured aggregate on the behavior of the concrete compressive strength up to 28 days was plotted in figure 4 (c) \& (d). It can be reported that the concrete compressive strength increased by using cured aggregate, while there is no effect on the compressive strength by increasing the solution used for aggregate curing from $10 \%$, to $20 \%$. 


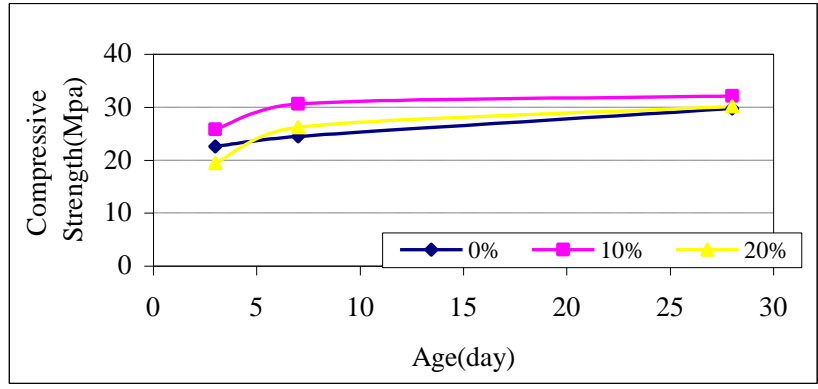

a) $0 \%$ silica fume addition.

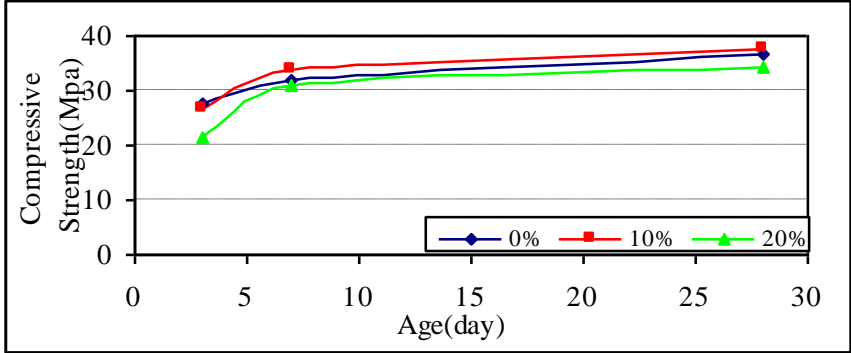

b) $5 \%$ silica fume addition.

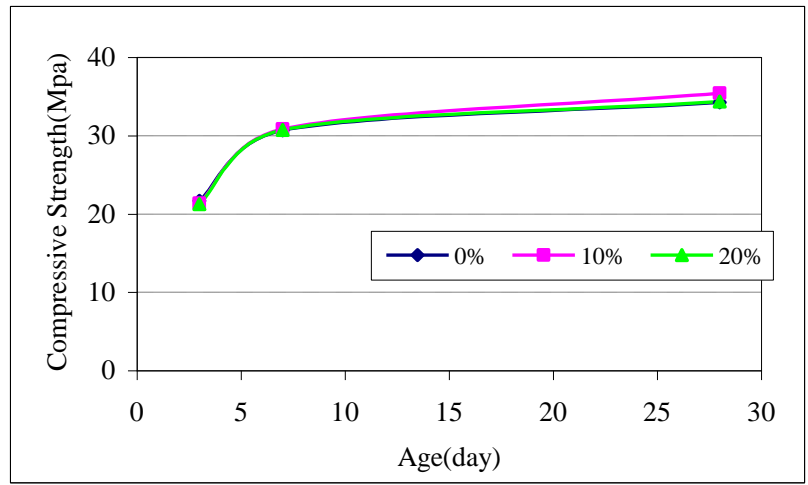

c) $10 \%$ silica fume addition.

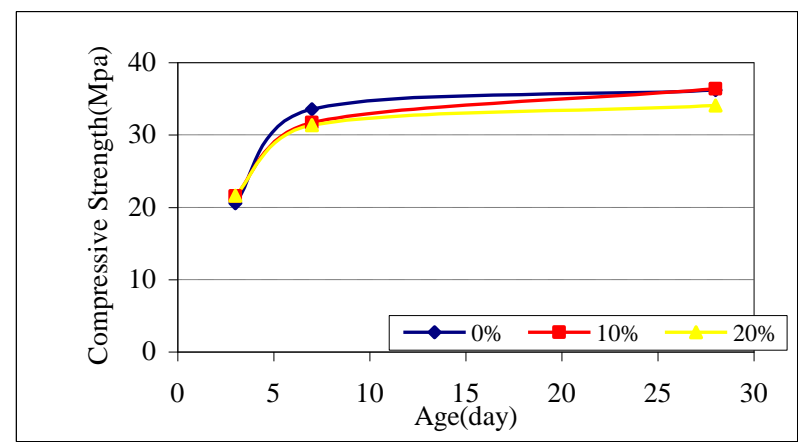

c) $5 \%$ silica fume addition.

Figure 4: Effect of adding Silica fume on compressive strength for CHBA concrete for different cured aggregate solution concentration. 


\section{Flexural Strength:}

The effect of using cured aggregate by silica fume solution with different concentration $(0,10,20 \%)$ was illustrated in Figures 5 (a), (b)\& (c). From these figures it was observed for all silica fume content the flexural strength was increased by nearly the same rate up to 28 days for all silica fume content and for all cured aggregate.

The effect of silica fume addition on flexural strength of concrete made from CHBA without curing can be negligible. As shown in Figure 5 a , while it can be observed that, the effect of silica fume addition on flexural strength of concrete made from cured aggregate $(10 \%, 20 \%$ solution concentration) as shown in figure 5 (b)\& (c) can be measured.

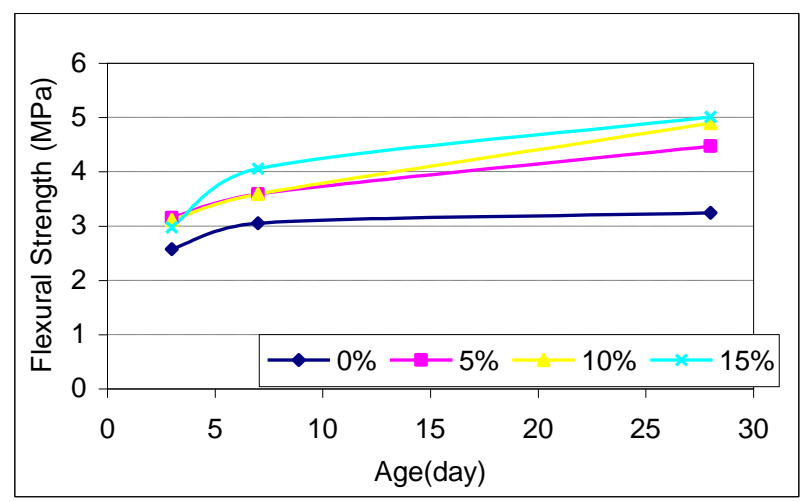

a) Cured Agg. with 0\% Silica fume solution .

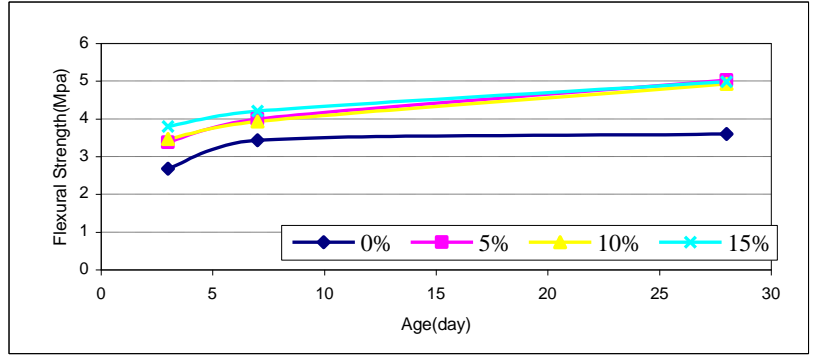

b) Cured Agg. with 10\% Silica fume solution.

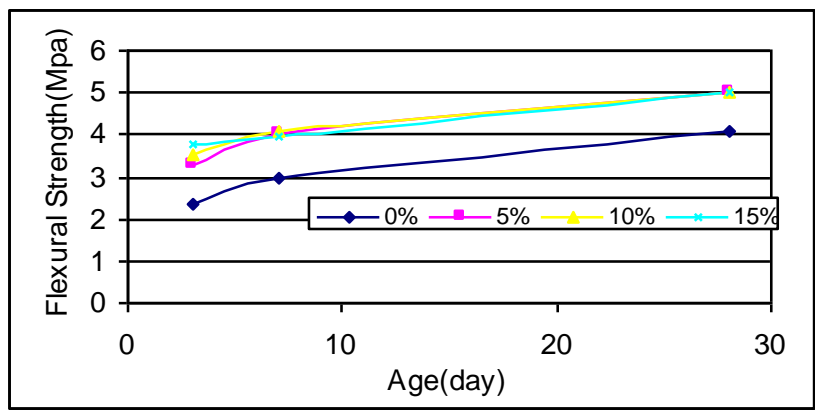

c) Cured Agg. with 20\% Silica fume solution .

Figure 5: Effect curing aggregate with of silica fume on Flexural strength for CHBA concrete at different percent of silica fume addition. 
The flexural strength of CHBA concrete at 28 days was selected to study the effect of curing aggregate and silica fume addition as shown in Figures 6 \& 7 , respectively. From these Figures it was found that the flexural strength of cured aggregate concrete increased by about $88.86 \%$ comparing by that occurred when used non cured aggregate. Also the flexural strength of cured specimens increased by about $81.24 \%$ by increasing silica fume content as addition from 5 up to $15 \%$ as shown in Figure 6.

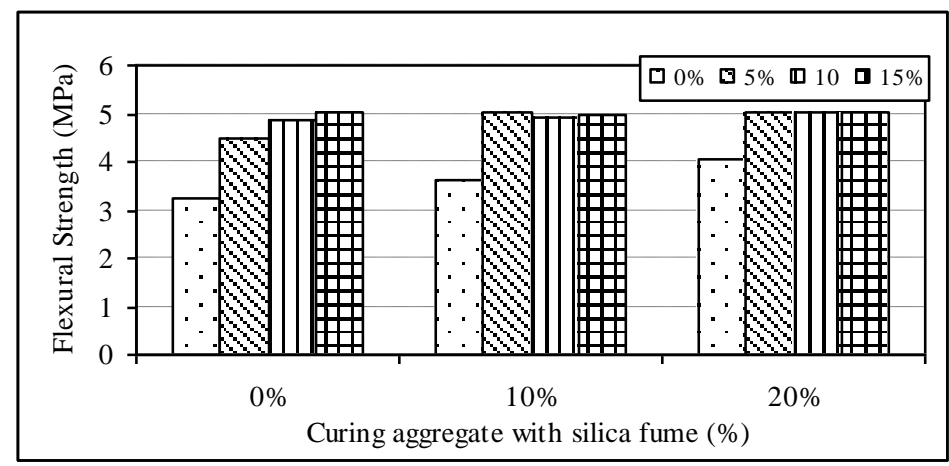

Figure 6: Effect of curing aggregate with silica fume on Flexural Strength of CBHA concrete for different cured aggregate solution concentration.

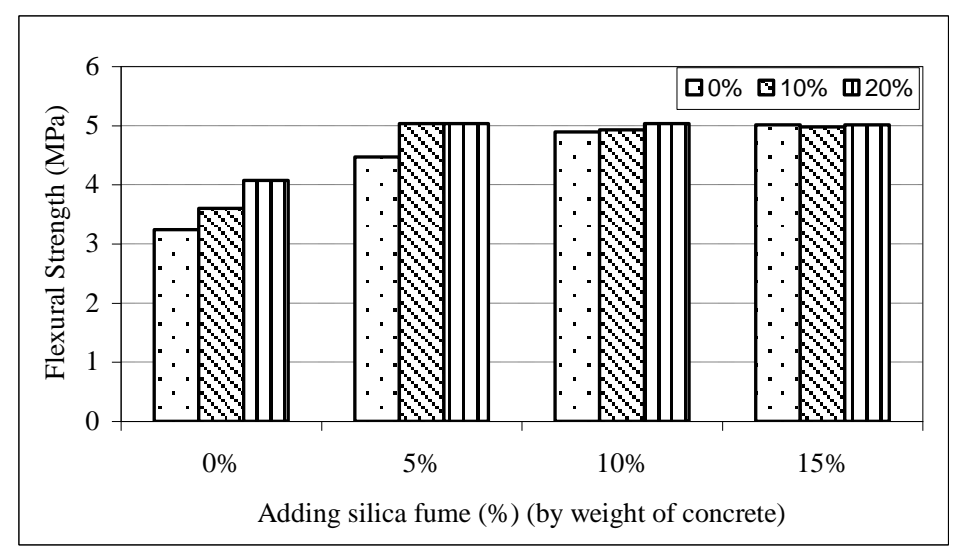

Figure 7: Effect of adding silica fume on flexural Strength for CBHA concrete for different cured aggregate solution concentration.

The effects of silica fume addition on flexural strength of CHBA concrete are illustrated in Figures 8 (a), (b), (c) \& (d). Figures 8 (a) \& (b) explain the effect of silica fume content $(0,5 \%)$ as addition on the concrete flexural strength of concrete containing cured aggregate $(0,10,20 \%$ silica fume solution concentration). From these figure it can be observed that the effect of using cured aggregate can be negligible up to 7 days, while the effect of using cured aggregate appeared clearly at 28 days flexural strength. By increase the silica fume content up to $15 \%$ the effect of using cured aggregate on the behavior of the concrete flexural strength up to 28 days was plotted in figure 8 (c)\& (d). It can be reported that the concrete flexural strength increased by using cured aggregate, while there is no effect on the flexural strength by increasing the solution used for aggregate curing from $10 \%$, to $20 \%$. 


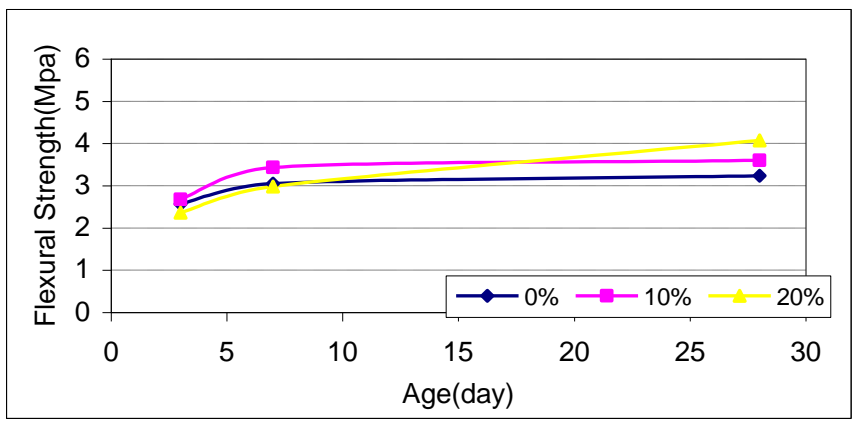

a) $0 \%$ silica fume addition (Control).

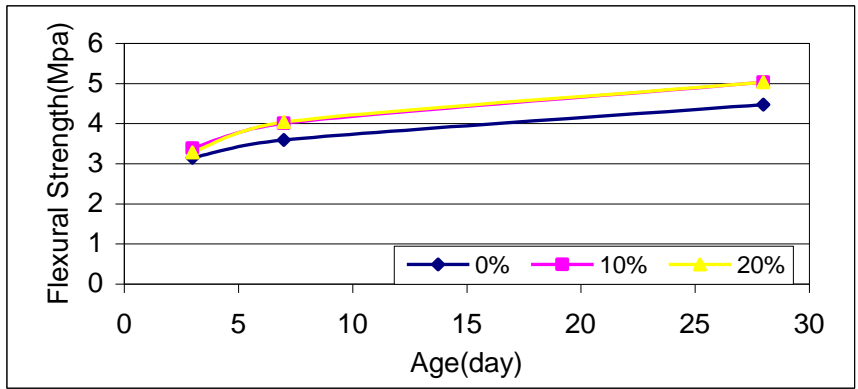

b) $5 \%$ silica fume addition.

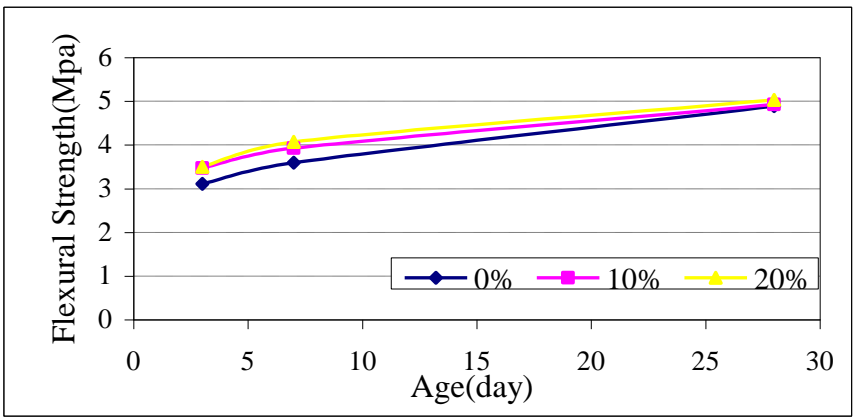

c) $10 \%$ silica fume addition.

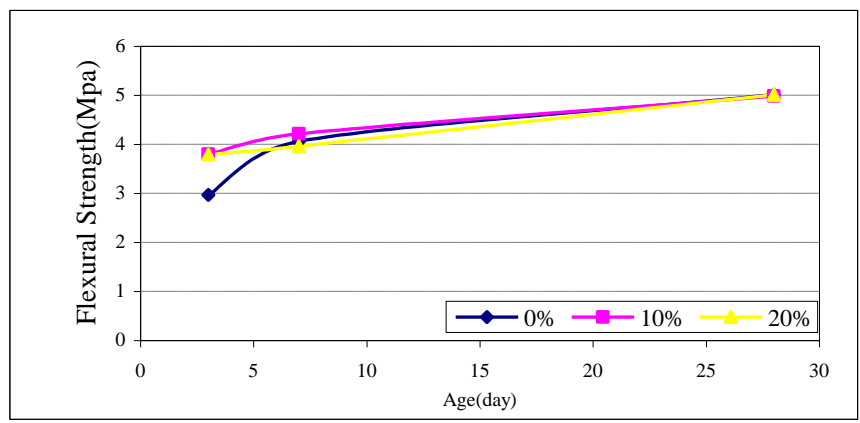

d) $15 \%$ silica fume addition.

Figure 8: Effect of adding silica fume on Flexural strength of CHBA concrete for different cured aggregate solution concentration. 


\section{COCLUSIONS}

The effect of using crushed block hollow aggregate cured by solutions of silica fume with different concentration (10\& $20 \%$ ) on the compressive strength and flexural strength of concrete was studies in this research, also the effect of using silica fume as an addition in combination with cured aggregate on the behavior of concrete strength was taken into consideration, the following conclusions are reported:

1- The compressive strength was increased by increasing silica fume addition for all types of aggregate.

2- Using cured artificial lightweight aggregate increase the compressive and flexural strength of concrete.

3- The effect of increase the concentration of silica fume solution for 10-20\% on strength of concrete can be negligible.

4- The mechanical properties of lightweight aggregate can be improved by using silica fume solution.

5- For production lightweight concrete with high strength to density ratio the idea of using cured aggregate by pozzolanic material solution must be taken into consideration.

\section{REFRENCES}

1. ACI committee 213 R-87, Guide for Structural Lightweight Aggregate Concrete, ACI Manual of Concrete Practice, Part 1, American Concrete Institute, Farmington Hills, 1987.

2. A. Short, W. Kinniburgh, Lightweight Concrete, $3^{\text {rd }}$ edition, Applied Science Puplishers, London, 1978.

3. I.B. Topcu, Semi - lightweight concretes produced by volcanic slags, Cement Concrete Research 27 (1) 1997 pp 15-21.

4. H. Al-Khaiat, M.N. Haque, effect of initial curing on early strength and physical properties of lightweight concrete, Cement Concrete Research 28 (6) 1998 pp 859866.

5. J.Alduaij, K. Alshaleh, M.N.Haque, K. Ellaithy, Lightweight concrete in hot coastal areas, Cement Concrete Research 21 (5-6) 1999 pp 453-458.

6. R. Demirboga, I. Orung, R. Gul, Effects of expanded perlite aggregate and mineral admixtures on the compressive strength of low- density concretes, Cement Concrete Research 31 (11) 2001 pp 1627-1632.

7. A.k.C. Duran Atis, Ergul Yasar, Fatih Ozcan, High-Strength Lightweight Concrete made with Socria Aggregate Containing Mineral Admixtures. Cement Concrete Research 33, 2003, pp 1595-1599.

8. R. Wasserman, A. Bentur, Effect of Lightweight Fly Ash Aggregate Microstructure on the Strength of Concretes, Cement Concrete Research 27, 1997 pp 525-537.

9. Min-Hong Zhang and E. Gorv, mechanical properties of High-Strength lightweight concrete, ACI Materials Journal, V. 88, No. 3, May-June 1991, pp 240-247.

10. Ilker Bekir Topcu, Semi-lightweight concrete produced by volcanic slags, cement and concrete research, Vol. 27, No. 1, 1997, pp 15-21. 


\section{الخلاصة}

\section{دراسة سلوك الخرسانة متوسطة الوزن المنتجة باستخدام كسر الطوب الطفلي}

في هذا البحث تم دراسة سلوك الخرسانة منوسطة الوزن المنتجة باستخدام كسر الطوب الطفلي • وحيث أن كسر الطوب يعتبر من نواتج الهدم ومصانع الطوب المطلوب تدويرها لذا كان الاتجاه إلى استخدام

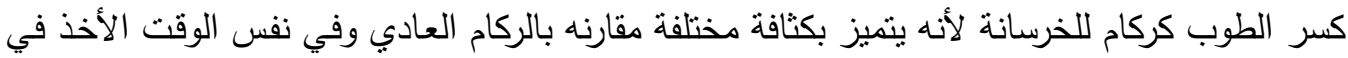

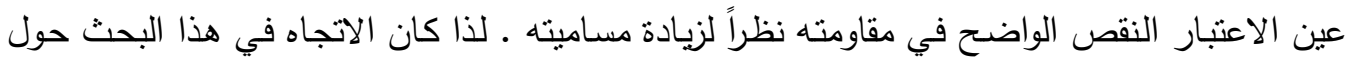

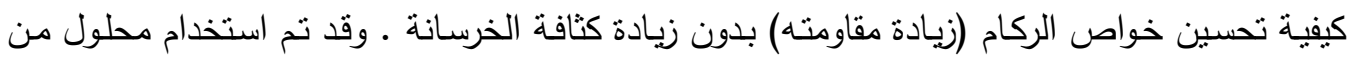
السيلكا فيوم بتركيزات مختلفة (10،20\%) لمعالجة كسر الطوب . وقد تم تصميم العديد من الخلطات الخرسانية لتغطية العوامل التي تم أخذها في الاعتبار مثل نوعية

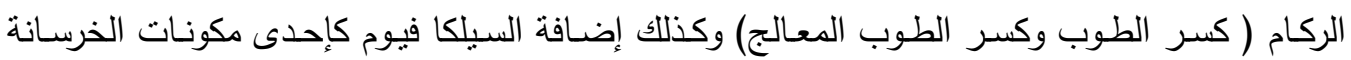
بنسب مختلفة (5،10،15\%) لدراسة سلوك العينات تحت تأثير أحمال الضغط والانحناء حتى 90 يوم .

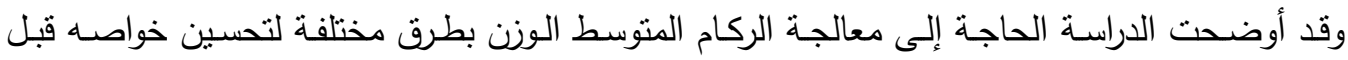

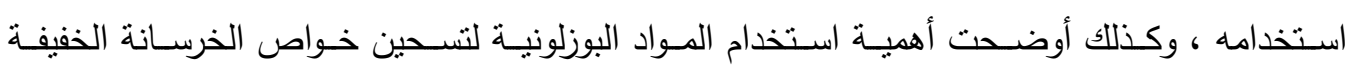

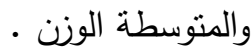

